\title{
AKTUÁLNÍ PROBLEMATIKA, TENDENCE A METODY ČESKO-MAĎARSKÉHO UMĚLECKÉHO PŘEKLADU
}

\author{
ANNAMÁRIA PÉNTEK A ELIZABETH KÖRÖSOVÁ
}

\begin{abstract}
This study deals with problematic features of Czech-Hungarian translation, focusing primarily on issues regarding translations of contemporary Hungarian literature, not only from the aesthetic point of view but from a linguistic one as well. The study examines possible methods and processes in Czech-Hungarian literary translations published from 2000, highlighting translation solutions for non-standard issues. Within translatological research, various translation solutions are examined, taking into account grammatical and lexical features of the two languages. The study includes a summary of Czech-Hungarian translation difficulties as a practical guide for novice translators. An analysis of frequent mistakes in translating from Hungarian to Czech makes up a portion of this work. The study presents a survey of the problems in translating calques, dialects, and slang. Translation solutions are demonstrated with specific examples from translations of three Hungarian novels: A köszívü ember fiai by Mór Jókai; Feleségverseny by György Spiró; and A lány, aki nem beszélt by Krisztina Tóth.
\end{abstract}

Keywords: Translation methods, Processes and tendencies, Translation mistakes, Hungarian, Translation from Hungarian, Translation into Czech, Hungarian literature, Mór Jókai, György Spiró, Krisztina Tóthová

\section{1. Úvodní část}

Studie reflektuje výsledky odborného translatologického výzkumu, který na česko-madarských beletristických překladech vydaných od r. 2000 do současnosti ukazuje a analyzuje aplikované překladatelské metody a př́stupy, a to $\mathrm{z}$ aspektu teoretického, kritického i praktického. Kolmanová (2017: 112) k této problematice poznamenává: „V oblasti translatologie středoevropského regionu se často setkáváme s tím, že se české odborné překladatelské práce věnují z důvodu jazykové př́ibuznosti a dostupnosti převážně slovanským konfrontacím, zatímco mad’arská oblast zůstává většinou mimo pozornost." Můžeme tedy říci, že tento výzkum, který lze pokládat za první komplexnější zpracování v oblasti současné česko-madarské translatologické problematiky, rovněž potvrzuje aktuálnost zkoumání překladu mezi středně velkými jazyky a kulturami a představuje obohacení translatologického výzkumu obecně. Dủležitou součástí našeho 
výzkumu i této studie je shrnutí česko-madarských překladatelských úskalí1 jako praktické pomůcky pro začínající překladatele, jimiž jsou převážně studenti z katedry Středoevropských studií na Filozofické fakultě Univerzity Karlovy.

Studie se na základě výzkumu soustředí na problematiku uměleckého překladu současné madarské literatury jak z hlediska literárně estetického, tak z hlediska jazykovědného.

Cílem výzkumu je ukázat, jak profesionální překladatelé pracují s textem jako uměleckým dílem a zároveň nastínit začínajícím překladatelům možné postupy a metody při samotném procesu překládání. Rovněž poukazujeme na současné tendence česko-madarské translatologie. Vedle interpretační a stylistické roviny se zaměřujeme na různá překladatelská řešení, jak gramatická, tak lexikální, ale také na jazykové roviny, počínaje rovinou morfologickou až po rovinu syntaktickou.

Z dřivější vypracované bakalářské práce (Péntek 2016) víme, že dobový úzus ve 20. století měl značný vliv na používané překladatelské metody. Předchozí výzkum nám ovšem potvrdil, že překladatelské metody nejsou ovlivněny pouze dobovou tendencí. Značnou roli hraje i subjektivní faktor, tedy př́stup překladatele. $V$ překladech současné literatury proto očekáváme nejen př́tomnost nových překladatelských tendencí (napřr. ústup nebo vymizení tabuizace), ale také individuální a subjektivní řešení překladů. Pro nynější výzkum jsme vybraly konkrétní překlady, na kterých ukazujeme různorodost překladatelských řešení. Na uvedených př́kladech, doprovozených našimi komentáři, se budou moci začínající překladatelé seznámit s určitými možnostmi překladatelských východisek.

Ve výzkumu vycházíme především z námi nastavených klasifikačních kritérií, pomocí nichž lze popsat vlastnosti překladového textu. Konkrétní překladatelská řešení demonstrujeme na vybraných př́kladech překladů madarské beletrie. $Z$ nich do studie nyní vybíráme ukázky z románů Synové muže kamenného srdce od Móra Jókaiho, Žena, propánakrále! od Györgye Spiróa a Dívka, která nemluvila od Krisztiny Tóthové.

Z výzkumu prezentuje tato studie ukázky z problematiky doslovného překladu a adekvátních či méně adekvátních metod používaných při řešení převodu dialektu ${ }^{2}$ či slangu.

\section{Dosavadní výsledky výzkumu}

Výzkum navazuje na bakalářskou práci, jejímž cílem bylo porovnat používané překladatelské metody v českých a slovenských překladech madarských děl z první a druhé poloviny 20. století a najít společné či odlišné rysy překladů. Výzkumná část práce si kladla za cíl identifikovat textové odlišnosti a podle vlastních stanovených kritérií určit použité překladatelské metody. Následně byl vytvořen z nalezených odlišností systém pro komparaci použitých metod $\mathrm{v}$ daném období. Na základě porovnání jednotlivých překladů se ukázalo, že stanovená očekávání byla správná, avšak z důvodu velkého množ-

1 O rozdílném repertoáru prostředků v pracovních jazycích mluví např. Jiř́i Levý ve stati Geneze a recepce literárního díla (1971b).

2 Při převodu dialektu a dalších nespisovných jazykových forem se v překladech důsledkem historického soužití Madarů a Slováků často setkáváme s problematikou madarsko-slovenské diglosie (zde viz 3.a), avšak zde se rozboru této rozsáhlé problematiky nevěnujeme. 
ství výjimek - které značně ovlivnily shrnutí celého výzkumu - nebylo možné výsledek jednoznačně vymezit. Během výzkumu bylo nalezeno vícero řešení jednotlivých aspektů. Stanovené zásady se proto ukázaly jako přiliš obecné. Na první pohled se může zdát, že se výzkum snažil zejména zpochybnit překladatelské tendence, ale pro nastínění komplexnosti tohoto tématu bylo důležité ukázat nejen shodující se metody, ale i odlišné aspekty. Jak již bylo zmíněno na začátku studie, překladatelská tradice značnou mírou ovlivňuje používané metody, nicméně jsou místa, kde překladatel zvolí tzv. „vlastní cestu“.

\section{Přehled translatologického úzu od 20. století až do současnosti}

I v česko-mad’arské relaci platí, že v první polovině 20. století se překladatelé snažili dodržovat především adekvátnost překladu, což vedlo mnohdy k oslabení metody doslovného překladu. Konkrétněji to znamená, že se snažili přeložit (případně substituovat) cizí výrazy, aby měl čtenář pocit, že čte originál, nikoliv překlad. Takový př́ístup se projevil zejména $\mathrm{v}$ př̀kladu vlastních jmen nebo $\mathrm{v}$ reáliích.

V druhé polovině 20. století dochází ke změnám v překladatelských postupech, svoji roli hraje i politický či ideologický tlak. Prioritou zůstalo nadále zachování primárního významu díla, nicméně překladatelé se začali orientovat i na cílového čtenáře a snažili se rozšírit jeho literární povědomí zachováním kulturního koloritu. Při překládání to znamenalo odvážnější používání substitucí.

Na zmíněnou tradici navazuje také současná tendence, která ukazuje, že udržení kulturní rozmanitosti je důležitým úkolem i pro překladatele (v této souvislosti mluví Jiří Levý (1971a: 147-157) o roli překladu při diverzifikaci domácí literatury). Čtenář by si měl být vědom, že čte překlad, avšak text by měl reprodukovat znění a ideu originálu. Tyto zásady tak otevírají pro překladatele nové možnosti při volbě postupů a metod. Kvůli novým přístupům $\mathrm{k}$ překladu jsme se rozhodly pokračovat v tomto výzkumu a zaměřit se pomocí př́kladi̊ na problematiku současné česko-mad’arské literární translatologie.

Vzhledem k tomu, že rozbor problematiky překládání beletrie zahrnuje bohatou škálu disciplín, jako je syntax, lexikologie, sociologie, psychologie apod., nastíníme zde pouze část možných překladatelských východisek a poskytneme především základní náhled na toto téma. Konkrétně se jedná o problematiku překládání současné mad’arské literatury z hlediska nestandardních jazykových vrstev. Podobně jako v předchozím výzkumu ukážeme používané postupy a metody překládání, včetně jejich identifikace dle stanovených kritérií (např. syntax, přirozenost výrazu, kompenzace apod.).

$\mathrm{V}$ rámci výzkumu byly ve zkoumaných dílech a na jejich překladech zjištěny rovněž rozsahové změny. Extrémním př́ípadem bylo vynechání téměř celé jedné kapitoly: „V původním madarském díle má tato kapitola rozsah zhruba tři strany, zatímco v českém překladu nacházíme pouze jeden odstavec v rozsahu 9 řádků. V celém románu si lze povšimnout kratších kapitol, než je tomu u originálu. Ve většině případů překladatel vynechává přírodovědecké popisy nebo delší opisné části apod." (Péntek 2016: 22). Dále jsme zaznamenaly nedodržování horizontálního dělení původního díla (odstavce, kapitoly), tabuizaci (lze najít většinou ve starších překladech), časové varianty (našly jsme i prŕklady archaizace nebo modernizace daného výrazu), národní varianty - s exotizací 
i naturalizací jsme se setkaly např̀. u názvů měst. Nyní uvedeme některé zajímavé příklady, zejména z oblasti dialektologie:

\section{a) Slovakizovaná mad’arština}

Onnan felülröl gyüvök harom egisz napok otatul fogva. Elgyütem egiszben utolsó stációig szerencsisen, Szunyoglakig. Hivatom birot, parancsolom forspontot. Van, de nincs. Hát hun van?... ${ }^{3}$

Celé tři dni jsem z domova na cestě sssem. Dorazil jsem ššštastně až na poslední ssstacii, do Suňoglaku. Volám rychtáře, ppporoučím si pppř́ípřež. Má, ale nemá. Kde tedy jest?... ${ }^{4}$

Jedu od nás shora už celé tri dni. Dojel som štastně, až na poslední štáciu, do Szúnyoglaku. Dal som si zavolat rychtára a rozkázal som si foršpon. Vraj je, ale není. Tak kde je?...5

V románu Móra Jókaiho najdeme postavu, která mluví tzv. idiolektem. Jedná se o pomad’arštěného Slováka, statkáře, který používá slovakizovanou mad’arštinu. Ohledně překladu řeči této postavy jsme našly dvě odlišné metody. Překladatel Hradský dle našeho mínění zvolil naprosto adekvátní postup: postava promlouvá slovensky a mísí se zde i české výrazy, kdežto u překladatele Mayerhoffera postava v řeči zadrhává. Mayerhoffer určitým způsobem naznačil jazykovou nedokonalost postavy, nicméně zvolil pro její vyjádření řečovou vadu a nikoli řešení, které by ukazovalo na nedokonalé užívání cizího jazyka. Naopak Hradský tuto jazykovou neobratnost zachoval a užitím slovenských prvků v češtině i vhodně lokalizoval.

\section{b) Obecná čeština}

Válaszolj már! Üvöltött rá Kolonc. - Ne csak a fejedet rázzad! ${ }^{6}$

„Vodpovídej normálně!“ zařval na ni Kláda. „Furt jen kejveš nebo vrtíš hlavou!“7

U překladu Roberta Svobody můžeme předpokládat, že užití obecné češtiny zvolil kvůli profánnosti projevu, expresivitě a stylistickým prvkům textu (mad’arština totiž nedisponuje jazykovou vrstvou, která by byla ekvivalentem obecné češtiny). Důležité je podotknout, že text originálu je gramaticky spisovný, zatímco v českém překladu vidíme protetické v-, furt, kejveš - tj. prvky odlišné na úrovni gramatické, fonetické, morfologické a stylistické roviny. V mad’arštině je zde pouze jeden prvek üvöltött (řval), který ve stylistické rovině posouvá výpověd’ do roviny obecné češtiny.

Obecná čeština je překladateli využívána zejména jako adekvátní způsob pro vyjádření určitých stylistických prvků a jevů, jedná se tak o formu kompenzace.

Jak prezentuje i výše uvedená ukázka, s užitím obecné češtiny se v překladech setkáváme $\mathrm{v}$ různých jazykových rovinách. K neadekvátnímu používání obecné češtiny často

\footnotetext{
Jókai, Mór: A köszívü ember fiai, s. 27.

Český překlad G. N. Mayerhoffera, 1924, s. 29.

Český překlad L. Hradského, 1964, s. 25.

Spiró, György: Feleségverseny, 2009, s. 143. (překlad vlastní: „Tak už odpověz!“ Ǩval na ni Kolonc. "A nevrt jen hlavou!")

7 Spiró, György: Žena, propánakrále! přeložil Robert Svoboda, 2016, s. 207.
} 
dochází tehdy, když překladatel např. zvolí její užití namísto dialektu, jazyk př́liš lokalizuje (pražská čeština) apod.

„Be akarok menni, itt lakok.”8

„Chci dovnitř. Já tady bydlím. “9

V madarštině lze poslední dobou v mluveném jazyce sledovat nesprávné časování tzv. ikových sloves ${ }^{10} \mathrm{v} 1$. os. singuláru. Tento fenomén je charakteristický pro nestandardní mad’arštinu. Správně by tvar slovesa měl být lakom (bydlím), nikoli lakok. Překladatelova volba lehce hovorového výrazu v tomto případě je adekvátní, protože se nejedná o regionální jazykový jev.

Př́klady zde uvedené jsou pouze ukázkou pro představu možného překladu jazykových vrstev. Širší vysvětlení bude prezentováno ve výsledcích výzkumu.

\section{K příručce pro začínající české překladatele z madarštiny}

Jak již bylo výše zmíněno, součástí výzkumu je rovněž práce, která se zabývá česko-mad’arskými překladatelskými úskalími a která by měla být - v duchu preskriptivního přístupu $^{11}$ - praktickým pomocníkem pro začínající překladatele. Vycházíme $\mathrm{z}$ teze, že překlad, a to především překlad uměleckého textu, je vždy kreativním procesem, a proto při překládání zpravidla nelze dojít $\mathrm{k}$ jedinému možnému výsledku, ani podat přesný „návod“, jak překládat, což je třeba začínajícím překladatelům rovněž připomenout.

$\mathrm{V}$ této studii představíme jen některé problémy, s nimiž jsou začínající překladatelé z madarštiny (ať už s rodným jazykem českým, nebo mad’arským) konfrontováni nejčastěji, a které brání zdařilému překladu.

Na vybraných prríkladech českého překladu Dívka, která nemluvila od překladatelky Eleonóry Tamar demonstrujeme správná i nesprávná řešení. Základ př́ručky tvoří komparace výchozích textů, které dle našeho mínění obsahují kritické body, s jejich překlady a př́slušnými komentáři.

\section{5. Úskalí překladu}

$\mathrm{V}$ příručce se mohou budoucí překladatelé seznámit s překladatelskými úskalími $\mathrm{z}$ různých hledisek. Součást příručky tvoří analýza chyb ${ }^{12}$, která se zaobírá jejich identifikací a konkrétně poukazuje na ty nejčastější.

8 Spiró, György: Feleségverseny, 2009, s. 120.

9 Spiró, György: Žena, propánakrále! přeložil Robert Svoboda, 2016. s. 173.

10 Skupina sloves, která ve 3. os. sing. přít. č. končí na koncovku -ik a v singuláru používá odlišné koncovky než jiné skupiny sloves.

11 Viz např. praxeológia prekladu u Antona Popoviče (1975).

12 „... chyby v překladu však nemusí být vždy chybami v pravém slova smyslu, tj. prohřešky proti kvalitativním rozdílům mezi východiskovým jazykem a češtinou, nýbrž také - a to mnohem častěji - chybami v širokém smyslu stylistickými, kam řadíme jednak př́ípady neobratného zacházení s mateřštinou, jednak chyby podmíněné tím, že jednotlivé jazyky využívají stejných (resp. podobných) systémových 
Pozornost věnujeme primárně možným chybám gramatické a lexikální povahy, zaměřujeme se zejména na chyby morfologické, lexikální a frazeologické. Do př́ručky jsme také zahrnuly chyby při přejímání vazeb a výrazů, které v češtině sice existují, ale mají odlišné stylistické uplatnění. Výsledný překlad poté působí na čtenáře stylisticky neobratně.

Z našeho dosavadního výzkumu vyplývá, že začínající překladatelé nejčastěji chybují např́klad v přenesení slovních spojení a frazeologismů z jednoho kulturního prostředí do druhého a oslabují tak výpověd výchozího textu. Dále mnohdy inklinují ke kopírování madarského slovosledu, pádů a slovních druhů. $U$ př̀kladatelů $s$ madarským mateřským jazykem dochází velmi často $k$ užití nesprávného slovesného vidu a k chybování v mluvnické shodě. ${ }^{13} \mathrm{~V}$ následujících ukázkách z již zmíněného díla, Dívka, která nemluvila, uvedeme několik chyb překladatelky Eleonóry Tamar a graficky zvýrazníme jednotlivá úskalí při překladu.

Př́klady některých chyb:

\section{a) Doslovný překlad slovních spojení a frazeologismů}

Erre megmutatták, hogy gombát ugyan nem leltek, de találtak egy gyönyörüséges kislányt. Olyan szép, amilyet hetedhét faluban se láttak soha errefelé. ${ }^{14}$

Pochlubili se mu, že houby sice nenašli, ale našli překrásnou holčičku. Takovou krásu ještě nikdo neviděl ani za devaterými dědinami. ${ }^{15}$

V této ukázce překladu se jedná o ustálené slovní spojení, jehož př́vlastek překladatelka vzhledem k ustálené formě nesprávně skloňuje. Správná forma by byla takto: $z a$ devatero dědinami.

\section{b) Nesprávné užití slovesného vidu}

Várta az ember, hogy mi lesz, de amikor lenézett, hogy kijött-e már az a fiúgyerek, aki segít neki gödröt ásni meg tüzet rakni, csak egy nagy szemet látott. ${ }^{16}$

Muž čekal, co bude, ale když se podíval, jestli už je venku ten chlapec, který mu pomůže kopat jámu a rozdělat oheň, viděl jen jedno velké oko. ${ }^{17}$

Překladatelka zde zvolila doslovný překlad slovního spojení mi lesz (tj. co bude). Ačkoli je překlad lexikálně správný, nepůsobí na českého čtenáře správně po stránce stylistické. Př́hodným řešením by bylo přidat do věty verbum: Muž čekal, co se bude dít...

Dále je $\mathrm{v}$ překladu patrná záměna dokonavého slovesa za nedokonavé. Sloveso viděl by mělo být nahrazeno slovesem uviděl či spatřil.

prostředků v konkrétním textu různou měrou, ev. v odlišných situacích“ (Kufnerová, Skoumalová et al. 1994: 48).

13 Vycházíme z praxe česko-madarských překladatelských seminářů konaných na Katedře středoevropských studií.

14 Tóthová, Krisztina: A lány, aki nem beszélt, Budapest: Móra könyvkiadó, 2015, komiks, nestr.

15 Tóthová, Krisztina: Dívka, která nemluvila, přeložila Eleonora Hamar, Praha: Baobab, 2018, s. 21.

16 Tóthová, Krisztina: A lány, aki nem beszélt, Budapest: Móra könyvkiadó, 2015, komiks, nestr.

17 Tóthová, Krisztina: Dívka, která nemluvila, přeložila Eleonora Hamar, Praha: Baobab, 2018, s. 11. 


\section{c) Doslovný překlad větné konstrukce, kopírování madarského slovosledu}

Amikor a tavasz első melegei érkeztek, az asszony megint fájlalni kezdte a hasát. Nőt, nőt újra a has egész nyáron, és őszre már megint akkora lett, mintha az asszony meg akarna halni. ${ }^{18}$

Když přišla první jarní tepla, žena si znovu začala stěžovat na bolesti břicha. Břicho jen rostlo, rostlo celé léto a s podzimem bylo zas tak veliké, jako kdyby se žena chystala umř́t. ${ }^{19}$

Kopírováním celé větné konstrukce, včetně nominativu, vznikla stylisticky neobratná věta. Méně rušivě by působila varianta s užitím instrumentálu: S prríchodem prvních jarních...

Mondta, hogy jó, ássák el. Húztak egy kis földhányást a szemre, az meg csak pislogott. Nemsokára már nem is látszott más belöle, csak egy világos folt, mintha egy apró tócsa tükrözné az eget a fák között. Kicsit ki is folyt a vize, mert sírt a szem, amikor az ember $\underline{\text { meg az asszony távolodott az úton. }}{ }^{20}$

Přitakala tedy, dobře, at’ oko zakopají. Nahrnuli na ně hromádku hlíny a oko nestačilo mrkat. Zanedlouho z něj už nebylo vidět nic víc než světlou skvrnku, jako kdyby mezi stromy malinká kaluž odrážela nebe. Trošku vody z ní vyteklo, protože oko, když od něho muž a žena po cestě odcházeli, plakalo. ${ }^{21}$

Výsledkem doslovného překladu a kopírováním madarského slovosledu jsou méně srozumitelné věty. Bylo by př́ihodné změnit stavbu věty takto: Zanedlouho $z$ něj už nebylo vidět nic víc než světlou skvrnku, jako kdyby malinká kaluž odrážela mezi stromy nebe. Vyteklo z ní (T) i trochu vody (R). Při překládání je důležité dodržet správné větné členění českého jazyka - v neutrálním sdělení stojí téma na začátku a réma na konci věty. Může však dojít také $\mathrm{k}$ tematizaci rématu - réma první věty se při něm stává tématem věty následující.

\section{d) Změna slovesného způsobu}

Mert ugyan ki akarna magának olyan lányt, aki csak cserreg, mint a szarka, nem szól soha egyetlen emberi szót sem?22

Kdopak bude chtít nevěstu, která neumí než skřehotat jako straka a neřekne nikdy jediné lidské slovo?23

Jelikož je jak pro češtinu, tak pro mad’arštinu přirozené používání kondicionálu, nemuselo $\mathrm{v}$ překladu dojít ke změně slovesného způsobu. Změna slovesného zposobu a užití budoucího času nejsou v uvedené větě př́liš vhodným řešením. Začátek věty by zněl lépe takto: Kdopak by takovou nevěstu viobec chtěl...

18 Tóthová, Krisztina: A lány, aki nem beszélt, Budapest: Móra könyvkiadó, 2015, komiks, nestr.

19 Tóthová, Krisztina: Dívka, která nemluvila, přeložila Eleonora Hamar, Praha: Baobab, 2018, s. 9.

20 Tóthová, Krisztina: A lány, aki nem beszélt, Budapest: Móra könyvkiadó, 2015, komiks, nestr.

21 Tóthová, Krisztina: Dívka, která nemluvila, přeložila Eleonora Hamar, Praha: Baobab, 2018, s. 13.

22 Tóthová, Krisztina: A lány, aki nem beszélt, Budapest: Móra könyvkiadó, 2015, komiks, nestr.

23 Tóthová, Krisztina: Dívka, která nemluvila, přeložila Eleonora Hamar, Praha: Baobab, 2018, s. 25. 


\section{e) Stylisticky neobratné zacházení se slovesem šlapat}

Asszony nem szeretett volna, ha az ember megveri, ezért megígérte, hogy nem hal meg. Gyalogolt tovább. ${ }^{24}$

Žena si nepř́ála, aby jí muž nařezal, proto mu slíbila, že neumře. Šlapala dál. ${ }^{25}$

Vzhledem k charakteru díla, které je pohádkou, se volba tohoto slovesa nejeví jako správná. Za méně rušivé sloveso bychom mohli dosadit následující: Kráčela dál. Rovněž místo slovesa nařezal by se zde nabízelo spiše sloveso zbil.

Ment, vitte haza a forrás vizét, lépegetett a szekérnyomban, kaptatott fel a dobra, ereszkedett le a völgybe, lépkedett a földeken, át az árokon. ${ }^{26}$

Šla a šla, šlapala si to $v$ kolejích vyjetých povozy, šplhala do kopců, sestupovala do údolí, kráčela přes pole a přes př́kopy. ${ }^{27}$

Na další vybrané ukázce vidíme, že překlad nebrání českému čtenáři v porozumění, nicméně s ohledem na žánr pohádky by bylo vhodnější zvolit sloveso typu cupitala.

\section{h) Neobratný výraz}

- Mit szültél te nekem? - kérdezte mérgesen az ember. ${ }^{28}$

= Co jsi mi to porodila? = ptal se muž hněvivě..$^{29}$

Překladatelka zde mohla zvolit variantu volnějšího překladu či zvolit srozumitelnější př́slovce jako například nahněvaně, rozzlobeně. Mimo to je očividné chybné přenesení madarského způsobu zaznamenávání prrímé řeči do českého textu. $\mathrm{V}$ českém jazyce se zapisuje prímá řeč pomocí uvozovek.

Na vybraných ukázkách byla pozornost věnována pouze některým bodům, na které jsme v rámci studie chtěly upozornit, další př́klady budou prezentovány v komplexních výstupech $\mathrm{z}$ výzkumu.

Závěrem bychom rády sumarizovaly nejčastějši chyby a úskalí, se kterými se začínající česko-madarský překladatel setkává. První chybou je nesprávná interpretace madarské syntaxe a jejího významu (v madarštině mnohdy činí nesnáze složitější větné konstruk$\left(\mathrm{e}^{30}\right)$. Dále by se měl překladatel při překladu vyvarovat především vlivu madarského slovosledu. I když je v obou jazycích slovosled flexibilní, neznamená to, že je nahodilý či shodný. Základní slovosled madarské oznamovací věty je tvořen následovně: podmět - předmět - přísudek, kdežto $\mathrm{v}$ českém jazyce je pořadí takovéto: podmět - př́sudek - předmět. Většina překladatelských úskalí tak vzniká při konstitutivním posunu čili

\footnotetext{
Tóthová, Krisztina: A lány, aki nem beszélt, Budapest: Móra könyvkiadó, 2015, komiks, nestr.

Tóthová, Krisztina: Dívka, která nemluvila, přeložila Eleonora Hamar, Praha: Baobab, 2018, s. 8.

Tóthová, Krisztina: A lány, aki nem beszélt, Budapest: Móra könyvkiadó, 2015, komiks, nestr.

Tóthová, Krisztina: Divka, která nemluvila, přeložila Eleonora Hamar, Praha: Baobab, 2018, s. 28.

8 Tóthová, Krisztina: A lány, aki nem beszélt, Budapest: Móra könyvkiadó, 2015, komiks, nestr.

29 Tóthová, Krisztina: Dívka, která nemluvila, přeložila Eleonora Hamar, Praha: Baobab, 2018, s. 8.

30 Častým úskalím pro začínající překladatele bývá správný překlad mad’arského způsobu přivlastňování: „Slovosled členů přivlastňovací vazby (která je v češtině vyjádřena genitivem) je v madarštině zpravidla opačný něž v češtině. V madarštině je na prvním místě vlastník, tedy člen přivlastňovací (komu/ čemu něco patří), a na druhém místě člen přrivlastněný (řídící), tedy vlastnictví (to, co vlastníkovi patří)“"(Schreierová 2018: 187).
} 
posunu, který je dán rozdíly mezi pracovními jazyky. Práce dále upozorňuje na problematiku překladu ustálených spojení a frazémů, pádů, slovních druhů (např. na př̀eklad mad’arského slovního druhu slovesných jmen, tzv. igenevek, což jsou různé druhy infinitivů a příčestíi ${ }^{31}$, který bývá jedním z nejobtížnějších) a slovních spojení. Nejschůdnějším řešením překladů se tak zdá být spojení obou metod, kdy překladatelé usilují o to, aby se co nejvíce přiblížili cílovému jazyku a kultuře, a to i formou volnějšího překladu.

K zdařilému výsledku překladatelské práce je tedy nutná patřičná oboustranná jazyková kompetence, nebot’ „překládat znamená pracovat nejen s jazykem cizím, ale především s mateřským“ (Kufnerová, Skoumalová et al. 1994: 3). Jak jsme již zmiňovaly v úvodu, výstup výzkumu představuje první souhrnnou translatologickou práci, která se věnuje specifičnosti překladu v česko-mad’arské relaci a akcentuje pro ni specifická př̀kladatelská úskalí.

\section{POUŽITÁ LITERATURA}

Benešová, Michala, Dybalska Renata a Zakopalová Lucie (2013) Tvưrčí překlad ve výukovém procesu na polsko-českém príkladu, Praha: Karolinum.

Spiró, György (2009) Feleségverseny, Budapest: Magvető.

Spiró, György (2016) Žena, propánakrále!, Praha: Malvern.

Jókai, Mór (1924) Synové muže kamenného srdce: román, přeložil G. N. Mayerhoffer Praha: Fr. Borový. Jókai, Mór (1964a) A köszívü ember fiai: 1869. köt. 1. Budapest: Akad. Kiadó.

Jókai, Mór (1964b) Synové muže kamenného srdce, přeložil Ladislav Hradský, vyd. 2., v SNKLU 1. Praha: SNKLU.

Kolmanová, Simona (2016) 'A kortárs magyar irodalom cseh nyelvű fordításai; Dialektológiai kérdések magyar-cseh nyelvi viszonylatban', in I. Czetter, R. Hajba a P. Tóth: VI. Dialektológiai Szimpozion, Nitra: Katedra středoevropských studií, Univerzita Konstantina filozofa, 427-437.

Kolmanová, Simona (2017) 'Český havran, nebo mad’arský krkavec? Poznámky k teorii a praxi překladu ve středoevropském regionu (konfrontace překladatelských přistupi na mad’arských a českých překladech Havrana E. A. Poea)', in J. Januška a T. Berkes. Hungarobohemica Pragensia: Studie k 60. narozeninám Evžena Gála / Tanulmányok Gál Jenő 60. születésnapjára, Praha: Univerzita Karlova, Filozofická fakulta, 112-1265.

Kufnerová, Zlata (2009) Čtení o prekládání, Jinočany: Nakladatelství H\&H.

Kufnerová, Zlata, Zdena Skoumalová, Milena Poláčková, Jaromír Povejšil a Vlasta Straková (2003) Překládaní a čeština. Jinočany: H \& M Vyšehradská.

Levý, Jiř́ (1971a) ‘Bude teorie překladu užitečná překladatelům?’, in Miroslav Červenka (ed.) Bude literární věda exaktní vědou?, Praha: Československý spisovatel, 147-157.

Levý, Jiří (1971b) 'Geneze a recepce literárního díla', in Miroslav Červenka (ed.) Bude literární věda exaktní vědou?, Praha: Československý spisovatel, 71-143.

Péntek, Annamária (2016) Srovnání prekladatelských metod a postupư v překladech madiarské literatury do češtiny a slovenštiny první a druhé poloviny 20. století [online]. Dostupné z: https://is.cuni.cz/webapps /zzp/detail/166116 (access: 2019-03-26).

Popovič, Anton (1975) Teória umeleckého prekladu, Bratislava: Tatran.

31 Tyto „různé druhy infinitivů a přičesti“ jsou utvořeny od tvaru slovesa, mají vlastnosti podstatných a prýdavných jmen a příslovcí. Často je tedy překládáme pomocí zmíněných jmen. Do jisté míry je můžeme přeložit také užitím českého pasivu anebo přechodníků. Další možností je metoda volnějšího překladu s vytvořením vedlejší věty (A. P. - E. K.). 
Schreierová, Angelika (2018) 'Madarština pro Čechy. Několik poznámek o specifických rysech gramatické struktury a o slovní zásobě mad’arštiny', in Jiří Januška, Česko-mad’arské ob(z)ory: kapitoly z dějin česko-madiarských univerzitních vztahů, Praha: Karolinum.

Tóthová, Krisztina (2015) A lány, aki nem beszélt, Budapest: Móra könyvkiadó.

Tóthová, Krisztina (2018) Dívka, která nemluvila, přeložila Eleonora Hamar, Praha: Baobab.

\title{
RESÜMEE
}

Die Studie thematisiert das Thema des zeitgenössischen tschechisch-ungarischen literarischen Übersetzens insbesondere aus literaturästhetischer und linguistischer Hinsicht, bezieht sich aber auch auf die translatologischen Tendenzen im 20. und 21. Jahrhundert. Vorgestellt werden die vorläufigen Teilergebnisse zweier thematisch verwandter Forschungsprojekte zu tschechisch-ungarischen literarischen Übersetzungen, die nach 2000 veröffentlicht wurden. Im Fokus der Untersuchung stehen die angewendeten Übersetzungmethoden in lexikalischer und grammatikalischer Hinsicht (von der Morphologie bis zur Syntax), aber auch die verschiedenen Sprachschichten. Ein Teil der Forschungsarbeit konzentriert sich auf nicht-standardisierte Sprachschichten (z. B. Dialekte, Idiolekte, Slang) und deren Übersetzung. Der zweite Teil befasst sich mit der Analyse häufiger Fehler beim Übersetzen aus dem Ungarischen ins Tschechische. Diese Phänomene werden an Beispielen aus den Romanen A köszívü ember fiai von Mór Jókai, Feleségverseny! von György Spiró und A lány, aki nem beszélt von Krisztina Tóth gezeigt.

\author{
Annamária Péntek \\ Katedra středoevropských studií, Filozofická fakulta Univerzity Karlovy, Praha \\ ancsi17@centrum.sk \\ Elizabeth Körösová, \\ Katedra středoevropských studií, Filozofická fakulta Univerzity Karlovy, Praha \\ bettykoros@seznam.cz
}

